\title{
Peningkatan Keikutsertaan KB IUD Pasca Persalinan (Post Partum) dengan Penggunaan Flashcard Saat Homecare Kehamilan Trimester III Di BPM Soemidjah Kota Malang
}

\author{
Ervin Rufaindah ${ }^{1}$, Septiana Juwita ${ }^{2}$ \\ ${ }_{1,2}$ D III Kebidanan \\ ${ }^{1,2}$ STIKES Widyagama Husada \\ e-mail: ${ }^{1}$ ervinrufaindah@yahoo.com, ${ }^{2}$ septiana.juwita@gmail.com
}

\begin{abstract}
Abstrak
Meningkatnya angka persalinan tidak sebanding dengan peningkatan jumlah akseptor KB setelah melahirkan. Kontrasepsi setelah melahirkan mempunyai tujuan yaitu menjaga jarak kehamilan, mengatur kelahiran dan menghindari kehamilan yang tidak diinginkan. Keluarga Berencana Pasca Persalinan (post partum) adalah pelayanan KB yang diberikan kepada pasien setelah melahirkan sampai 42 hari setelah melahirkan. Penggunaan kontrasepsi postpartum dipengaruhi oleh salah satunya adalah konseling KB saat hamil. Akseptor KB terbanyak adalah kontrasepsi hormonal. Media konseling yang digunakan di BPM "S" adalah lembar balik, leaflet dan buku KIA, terkadang juga tidak menggunakan media. Rendahnya akseptor IUD dikarenakan ibu-ibu takut dengan proses pemasangan IUD, KB suntik dianggap lebih praktis, IUD dianggap lebih mahal dan dikarenakan faktor sosiocultural. Sehingga perlu diadakan sosialisasi media konseling yang praktis dan materi dapat tersampaikan dengan baik. Media konseling dapat digunakan saat home care sejak kehamilan trimester III, persalinan, nifas dan KB. Sehingga bisa meningkatkan pengetahuan ibu dan meningkatkan keikutsertaan KB IUD. Tujuan yang dikaji adalah bidan menerapkan flash card sebagai media konseling, meningkatkan pengetahuan dan keikutsertaan KB IUD. Populasi dalam pengabdian masyarakat ini adalah seluruh ibu hamil trimester III yang memeriksakan kehamilannya dan melahirkan di BPM (Bidan Praktek Mandiri) Soemidjah dengan mengggunakan teknik accidental sampling. Setelah dilakukan analisis menggunakan uji wilcoxon didapatkan $p=0,000$ kurang dari alfa 0,05 yang mempunyai arti ada pengaruh pemberian konseling terhadap perubahan pengetahuan. $68 \mathrm{ibu}$ hamil trimester III yang diberikan konseling menggunakan flash card terdapat $21 \mathrm{ibu}$ yang menjadi akseptor IUD pasca persalinan. Diharapkan setelah kegiatan ini, Bidan tetap memberikan konseling IUD menggunakan flash card sehingga makin banyak akseptor IUD.
\end{abstract}

Kata kunci: keikusertaan berKB; IUD; flash card; home care

\section{Abstract}

Increased labor rates are not comparable with the increase in the number of family planning acceptors after giving birth. Postpartum contraception has the goal of maintaining the distance of pregnancy, regulating birth and avoiding unwanted pregnancies. Post-partum family planning (post partum) is a family planning service that is given to patients after giving birth until 42 days after giving birth. The use of postpartum contraception is influenced by one of them is family planning counseling during pregnancy. The most contraceptive acceptors are hormonal contraception. The counseling media used in BPM "S" are flipcharts, leaflets and MCH books, sometimes also not using the media. The low acceptability of IUDs is because mothers are afraid of the IUD installation process, injection KB is considered more practical, IUDs are considered more expensive and due to sociocultural factors. So that, it is necessary to hold a counseling media socialization that is practical and the material can be conveyed well. Counseling media can be used during home care since the third trimester of pregnancy, labor, childbirth and family planning. So that it can increase maternal knowledge and increase participation in family planning. The objectives studied were midwives applying flash cards as a medium of counseling, increasing knowledge and participating in family planning IUDs. The population in this community service was all trimester III pregnant women who examined their pregnancies and gave birth in BPM Soemidjah using accidental sampling techniques. After analysis using the Wilcoxon test obtained $p=0,000$ less than alpha 0,05 which means there is an effect of giving counseling to changes in knowledge. 68 third trimester pregnant women who were given counseling using flash cards were 21 mothers who became acceptors of postpartum IUDs. It is expected that after this activity, Midwives continue to provide IUD counseling using flash cards so that more IUD acceptors. 


\section{PENDAHULUAN}

Hasil Survei Demografi dan Kesehatan Indonesia (SDKI) tahun 1991 sampai dengan tahun 2007 menunjukkan jumlah perempuan yang melahirkan di rumah sakit pemerintah dan swasta meningkat, namun jumlah persalinan yang meningkat ini tidak sebanding dengan jumlah akseptor KB setelah melahirkan. Ratarata akseptor $\mathrm{KB}$ setelah melahirkan hanya 5-10\%. Kontrasepsi setelah melahirkan mempunyai tujuan yaitu menjaga jarak kehamilan, mengatur kelahiran dan menghindari kehamilan yang tidak diinginkan. IUD adalah plastik berbentuk $\mathrm{T}$ seukuran uang logam yang ditempatkan di dalam rahim untuk mencegah kehamilan. Beberapa keunggulan penggunaan IUD diantaranya adalah aman digunakan untuk ibu menyusui, mengurangi risiko terkena kanker serviks dan kanker endometrium, tidak membuat gemuk seperti pil KB [3]

Keluarga Berencana post partum adalah pelayanan KB yang diberikan kepada pasien setelah melahirkan sampai 42 hari setelah melahirkan. Penggunaan kontrasepsi postpartum dipengaruhi oleh faktor sosioekonomi dan demografi, konseling kontrasepsi saat hamil, pengetahuan dan sikap KB postpartum. Konseling KB postpartum berpengaruh terhadap penggunaan kontrasepsi pasca persalinan. Beberapa penelitian menunjukkan peningkatan yang signifikan dalam penggunaan metode kontrasepsi efektif pada wanita melalui penyediaan leaflet dan konseling. Penelitian sebelumnya juga menyebutkan hal yang sama yaitu konseling KB dapat meningkatkan penggunaan kontrasepsi pada periode postpartum.

Konseling $\mathrm{KB}$ pada masa kehamilan juga telah diimplentasikan di Indonesia, akan tetapi angka kehamilan tidak diinginkan masih tinggi, disebabkan karena missed opportunities pelayanan KB pada pasca persalinan, belum optimalnya konseling sebagai sarana komunikasi informasi dan edukasi pelayanan keluarga berencana (KB), serta takut akan efek samping. Konseling kontrasepsi tidak dilakukan selama perawatan antenatal di Tanzania hal itu hanya diberikan pada kunjungan 6 minggu pasca persalinan tetapi banyak perempuan yang tidak hadir, terutama apabila kliniknya jauh dari rumah, dan bayi dalam keadaan sehat. Oleh sebab itu, pelayanan antenatal adalah kesempatan untuk menjangkau perempuan yang dinyatakan sulit diakses setelah melahirkan dengan konseling kontrasepsi. Pemberian konseling Keluarga Berencana dan metode kontrasepsi selama masa perinatal dapat meningkatkan kesadaran ibu untuk menggunakan kontrasepsi [2].

Dalam penyuluhan kesehatan diperlukan cara yang tepat, efektif mudah untuk meningkatkan pengetahuan yang baik. Hal yang cukup penting dalam penggunaan alat peraga adalah alat yang digunakan harus menarik sehingga menimbulkan minat para pesertanya [4]. Flash card adalah media konseling berupa kertas/kartu yang berisi informasi untuk memberikan pendidikan kesehatan. Keunggulan dari flash card yaitu mudah dibawa kemana-mana saat homecare sehingga dapat meningkatkan pengetahuannya yang akhirnya dapat meningkatkan keikutsertaan KB. Semakin baik media konseling maka semakin baik pula pesan yang ditangkap, yang pada akhirnya akan mengubah pengetahuan ibu [1].

Mitra yaitu BPM Soemidjah Kota Malang memberikan asuhan kebidanan mulai dari masa kehamilan, persalinan, nifas, BBL, neonatus, bayi dan balita, anak prasekolah, kesehatan reproduksi dan KB. Dalam pemberian asuhan kebidanan KB, BPM Soemidjah menggunakan media leaflet, buku KIA, lembar balik dan terkadang tidak menggunakan media. Macam-macam alat kontrasepsi yang disampaikan ke calon akseptor adalah KB alami, hormonal dan jangka panjang. Akan tetapi Akseptor KB terbanyak adalah kontrasepsi hormonal yaitu suntik 3 bulan, 1 bulan, pil dan implan. Rendahnya akseptor IUD dikarenakan kurangnya pengetahuan ibu tentang IUD pasca persalinan (post partum), kurangnya kesadaran ibu-ibu 
tentang IUD pasca persalinan (post partum), ibu-ibu takut dengan proses pemasangan IUD di dalam uteri, KB suntik dianggap lebih praktis, IUD dianggap lebih mahal dan dikarenakan faktor sosiocultural.

\section{SUMBER INSPIRASI}

Dengan adanya sosialisasi kepada BPM Soemidjah tentang media penyuluhan Flashcard untuk konseling IUD, diharapkan BPM dapat menerapkannya saat memberikan konseling KB. Dapat meningkatkan pengetahuan ibu hamil trimester III tentang KB IUD. Dapat meningkatkan keikutsertaan KB IUD Pasca Persalinan (Post Partum).

\section{METODE KEGIATAN}

Metode pelaksanaan Pengabdian kepada masyarakat dalam upaya Peningkatan Keikutsertaan KB IUD pasca partum adalah: 1) Pembuatan flashcard tentang KB IUD pasca partum, 2) Sosialisasi flashcard kepada BPM Soemidjah dengan peserta ibu soemidjah dengan 2 bidan yang bertugas di BPM tersebut, 3) Menerapkan flashcard sebagai media konseling KB IUD pada ibu hamil trimester III di BPM Soemidjah, 4) Melakukan homecare pada ibu hamil trimeter III dengan menggunakan flashcard sebagai media konseling KB IUD, 5) Evaluasi terhadap pengetahuan ibu hamil trimester III tentang KB IUD, 6) Supervisi terkait keikursertaan ibu dalam memilih IUD, 7) Pelaporan Pelaksanaan Program, dan 8) Penyusunan Rencana Tindak Lanjut.

\section{KARYA UTAMA}

\section{Hasil Pelaksanaan Kegiatan}

\section{Sosialisasi Flash Card kepada BPM Soemidjah}

Pelaksanaan kegiatan Sosialisasi Flash Card kepada BPM Soemidjah Kota Malang dilaksanakan pada hari Jum'at tanggal 03 Agustus 2018 bertempat di BPM Soemidjah Kota Malang. Kegiatan sosialisasi ini diikuti oleh Bidan Soemidjah, Bidan Ruri, Ervin
Rufaindah, S.ST., M.Keb (Dosen Kebidanan), Sulistyorini (Mahasiswa Kebidanan Semester IV), Nanda Evi (Mahasiswa Kebidanan Semester IV), Ni'mah M (Mahasiswa Kebidanan Semester II). Kegiatan ini dimulai pukul 15.00 s.d 17.00 WIB. Tujuan dari kegiatan sosialisasi ini adalah berbagi informasi tentang media konseling terbaru dengan menggunakan Flash Card untuk KIE IUD, sebagai bentuk pengabdian masyarakat dosen kebidanan STIKES Widyagama Husada Malang.

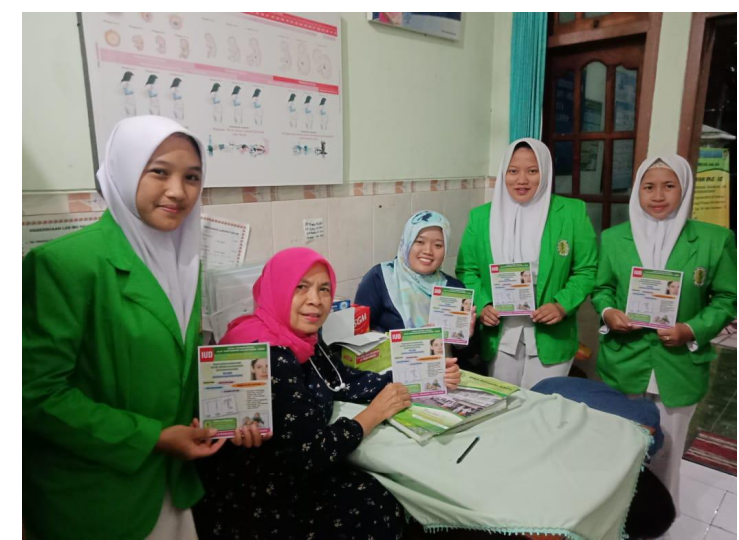

Gambar 1. Sosialisasi Flash Card di BPM Soemidjah Kota Malang

Setelah kegiatan sosialisasi ini, diharapkan BPM Soemidjah dapat menerapkan Flash Card sebagai media konseling IUD kepada ibu hamil trimester III, sehingga dapat meningkatkan pengetahuan dan keikutsertaan ibu sebagai akseptor IUD pasca persalinan. Flash card berisi informasi tentang keunggulan IUD, Waktu pemasangan IUD, gambar IUD serta gambar IUD yang telah terpasang di kavum uterus.

Akseptor KB terbanyak adalah kontrasepsi hormonal yaitu suntik 3 bulan, 1 bulan, pil dan implant. Media konseling yang digunakan di BPM "S" adalah lembar balik, leaflet dan buku KIA, terkadang juga tidak menggunakan media. Rendahnya akseptor IUD dikarenakan ibu-ibu takut dengan proses pemasangan IUD di dalam uteri, KB suntik dianggap lebih praktis, IUD dianggap lebih mahal dan dikarenakan faktor sosiocultural. Oleh sebab itu perlu adanya inovasi dalam penggunaan media konseling KB IUD. 


\section{Penerapan Flash Card Kepada Ibu Hamil Trimester III di BPM Soemidjah}

Pelaksanaan kegiatan Penerapan Flash Card Kepada Ibu Hamil Trimester III di BPM Soemidjah dilaksanakan mulai tanggal 03 Agustus 2018 - 30 September 2018. Kegiatan ini dilakukan jika ada ibu hamil trimester III yang datang memeriksakan kehamilannya ke BPM. Konseling KB IUD menggunakan Flash Card dilakukan oleh Bidan Soemidjah dan Bidan Ruri setelah melakukan pemeriksaan kehamilan. Urutan kegiatannya adalah Bidan melakukan anamnesa, pemeriksaan fisik, pemeriksaan penunjang sesuai indikasi kemudian memberikan konseling kehamilan sesuai kebutuhan dan memberikan konseling KB IUD. Sebelum konseling, Bidan memberikan kuesioner tentang KB IUD yang terdiri dari 5 pertanyaan yaitu pengertian IUD, keuntungan IUD, efek samping IUD, waktu pemasangan IUD dan tempat pemasangan IUD.
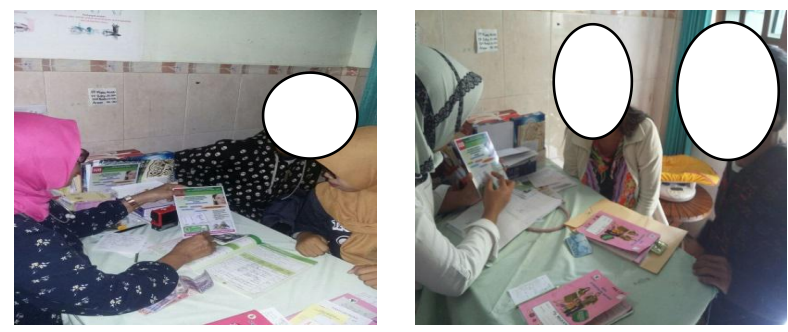

Gambar 2. Penerapan Flash Card di BPM Soemidjah

[5] faktor-faktor yang mempengaruhi Wanita Usia Subur (WUS) menjadi akseptor IUD adalah usia, pengetahuan dan dukungan suami.

\section{Karakteristik responden berdasarkan usia}

Usia responden dikategorikan menjadi 3 yaitu usia $<20$ tahun, 20-35 tahun dan $>35$ tahun berdasarkan resiko terjadinya komplikasi kehamilan. Berikut tabel tentang karakteristik responden berdasarkan usia.

Tabel 1. Karakteristik responden berdasarkan usia Agustus s.d September 2018 di Malang

\begin{tabular}{lll}
\hline \multicolumn{1}{c}{ Usia } & Frekuensi & Prosentase \\
\hline$<20$ tahun & 6 & $8,8 \%$ \\
$20-35$ tahun & 53 & $77,9 \%$ \\
$>35$ tahun & 9 & $13,2 \%$ \\
\hline Total & 68 & $100 \%$ \\
\hline
\end{tabular}

Tabel 1 menunjukkan bahwa sebagian besar responden berusia 20-35 tahun sebanyak 53 orang (77,9 \%) sedangkan usia beresiko tinggi sebanyak 22,1\% terbagi menjadi berusia kurang dari 20 tahun sebanyak 8,8\% dan usia lebih dari 35 tahun sebanyak 13,2\%.

Karakteristik responden berdasarkan dukungan suami

Dukungan dari suami responden dikategorikan menjadi 2 yaitu suami mendukung dan tidak mendukung. Berikut tabel tentang karakteristik responden berdasarkan dukungan suami.

Tabel 2. Karakteristik responden berdasarkan dukungan suami Agustus s.d September 2018 di Malang

\begin{tabular}{lll}
\hline \multicolumn{1}{c}{ Dukungan } & Frekuensi & Prosentase \\
\hline Mendukung & 30 & $44,1 \%$ \\
Tidak mendukung & 38 & $55,9 \%$ \\
& & \\
\hline Total & 68 & $100 \%$ \\
\hline
\end{tabular}

Tabel 2 menunjukkan bahwa sebagian besar responden tidak mendapat dukungan dari suami yaitu $55,9 \%$ sedangkan responden yang mendapat dukungan dari suami sebanyak $44,1 \%$.

\section{Karakteristik responden berdasarkan pengetahuan} sebelum dan sesudah konseling

Sebelum konseling, Bidan memberikan kuesioner tentang KB IUD yang terdiri dari 5 pertanyaan yaitu pengertian IUD, keuntungan IUD, efek samping IUD, waktu pemasangan IUD dan tempat pemasangan IUD. Setelah dilakukan analisis menggunakan uji wilcoxon didapatkan $p=0,000$ kurang dari alfa 0,05 yang mempunyai arti ada pengaruh pemberian konseling terhadap perubahan pengetahuan.

\section{Penerapan Flash Card Kepada Ibu Hamil Trimester} III saat home care

Pelaksanaan kegiatan Penerapan Flash Card Kepada Ibu Hamil Trimester III saat home care dilaksanakan mulai tanggal 03 Agustus 2018 - 30 September 2018. Kegiatan ini dilakukan dengan mengunjungi rumah ibu hamil untuk melakukan 
pemeriksaan kehamilan. Ada 4 ibu hamil yang dilakukan kunjungan rumah. Konseling KB IUD menggunakan Flash Card dilakukan oleh Ervin Rufaindah, S.ST., M.Keb selaku ketua tim beserta Septiana Juwita, S.SiT., M.PH, Kurnianti (mahasiswa kebidanan semester IV), Renita Septyarini (mahasiswa kebidanan semester IV) setelah melakukan pemeriksaan kehamilan. Urutan kegiatannya adalah Bidan melakukan anamnesa, pemeriksaan fisik, pemeriksaan penunjang sesuai indikasi kemudian memberikan konseling kehamilan sesuai kebutuhan dan memberikan konseling KB IUD.

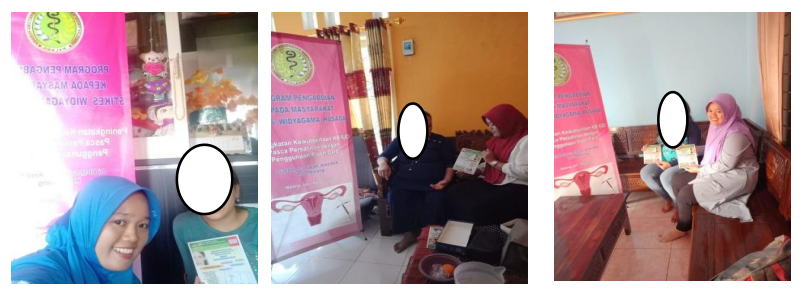

Gambar 3. Penerapan Flash Card saat homecare

Setelah dilakukan penerapan flash card di BPM Soemidjah dan saat homecare, dilakukan evaluasi kegiatan yaitu setelah persalinan tentang jumlah ibu nifas yang menjadi akseptor IUD. Dari 68 ibu hamil trimester III terdapat $21 \mathrm{ibu}$ yang menjadi akseptor IUD pasca persalinan.

\section{Pembahasan}

\section{Sosialisasi Flash Card kepada BPM Soemidjah}

Kegiatan pengabdian masyarakat yang diadakan di BPM Soemidjah Kota Malang ini mendapat respon positif dari Bidan, ibu hamil dan suami ibu hamil. Tujuan dari kegiatan sosialisasi ini adalah berbagi informasi tentang media konseling terbaru dengan menggunakan Flash Card untuk KIE IUD, sebagai bentuk pengabdian masyarakat dosen kebidanan STIKES Widyagama Husada Malang. Flash card berisi informasi tentang keunggulan IUD, Waktu pemasangan IUD, gambar IUD serta gambar IUD yang telah terpasang di kavum uterus.

Sosialisasi digambarkan sebagai proses dimana suatu inovasi dikomunikasikan melalui saluran tertentu dalam jangka waktu tertentu diantara para anggota suatu sistem sosial. Inovasi yang dimaksud disini adalah Program Keluarga Berencana yang ada dan dikomunikasikankan melalui saluran tertentu dalam hal ini sosialisasi dengan cara atau pendekatan komunikasi interpersonal secara intensif dengan hanya menggunakan media bahasa dalam moment-moment yang berbeda dengan akseptor atau calon akseptor. Dengan adanya sosialisasi media konseling menggunakan Flash Card ini diharapkan dapat diterapkan bidan saat memberikan asuhan sehingga dapat meningkatkan keikutsertaan KB IUD.

\section{Penerapan Flash Card Kepada Ibu Hamil Trimester III di BPM Soemidjah}

Kegiatan ini berhasil diterapkan kepada 68 ibu hamil selama 2 bulan, dengan mengidentifikasi usia, dukungan dari suami dan pengetahuan ibu hamil tentang KB IUD.

\section{Karakteristik responden berdasarkan usia}

Usia responden sebagian besar berusia 20-35 tahun sebanyak 53 orang $(77,9 \%)$ sedangkan usia beresiko tinggi sebanyak $22,1 \%$ terbagi menjadi berusia kurang dari 20 tahun sebanyak 8,8\% dan usia lebih dari 35 tahun sebanyak 13,2\%. Menurut Johana, 2013 Responden berusia di atas 20 tahun lebih memilih IUD karena secara psikologis usia 20 tahun mulai matang, bisa mempertimbangkan secara emosional dan nalar akan pentingnya manfaat penggunaan IUD. Usia di atas 20 tahun merupakan masa menjarangkan dan mencegah kehamilan sehingga pilihan kontrasepsi lebih ditujukan pada kontrasepsi jangka panjang [5]. Responden berusia kurang dari 20 tahun lebih memilih non IUD karena usia tersebut merupakan masa menunda kehamilan sehingga pilihan kontrasepsi selain dari IUD yaitu pil, suntikan, implan, dan kontrasepsi alami/sederhana.

\section{Karakteristik responden berdasarkan dukungan dari} suami

Dukungan dari suami responden dikategorikan menjadi 2 yaitu suami mendukung dan tidak mendukung. Sebagian besar responden tidak mendapat dukungan dari suami yaitu 55,9\% sedangkan responden yang mendapat 
dukungan dari suami sebanyak 44,1 \%. Setelah dilakukan wawancara kepada suami ataupun ibu hamil, suami tidak mendukung karena suami takut karena IUD dipasang di dalam uterus, beberapa juga pernah mendengar bahwa IUD bisa berpindah tempat, istri mengalami menstruasi lebih banyak dan lama, serta IUD bisa menimbulkan ketidaknyamanan saat berhubungan seksual.

Rendahnya dukungan suami membuktikan bahwa rata-rata suami responden belum berpengetahuan baik tentang IUD. Teori Lawrence Green mengemukakan bahwa faktor dukungan suami dapat dikatakan sebagai salah satu faktor yang memungkinkan suatu motivasi atau aspirasi terlaksana. Perpaduan antara pendidikan, pengetahuan dan dukungan suami dengan kemauan yang kuat dari istri dalam menetapkan pilihan pada alat kontrasepsi yang terbukti efektif tersebut membuahkan keputusan yang bulat bagi kedua pasangan dalam menggunakan kontrasepsi tersebut. Ambarwati mengemukakan bahwa persetujuan pasangan/suami berperan penting dalam pemilihan IUD. Pemasangan IUD membutuhkan kerja sama dengan suami karena alasan takut benangnya mengganggu saat bersenggama.

Karakteristik responden berdasarkan pengetahuan sebelum dan sesudah konseling

Sebelum konseling, Bidan memberikan kuesioner tentang KB IUD yang terdiri dari 5 pertanyaan yaitu pengertian IUD, keuntungan IUD, efek samping IUD, waktu pemasangan IUD dan tempat pemasangan IUD. Sebelum konseling dilakukan pretest dan setelah konseling dilakukan posttest untuk mengetahui perubahan pengetahuan. Setelah dilakukan analisis menggunakan uji wilcoxon didapatkan $p=0,000$ kurang dari alfa 0,05 yang mempunyai arti bahwa ada pengaruh pemberian konseling terhadap perubahan pengetahuan.

Responden yang mendapatkan konseling dengan baik cenderung memilih alat kontrasepsi dengan benar dan tepat sehingga menurunkan tingkat kegagalan $\mathrm{KB}$ dan mencegah terjadinya kehamilan yang tidak diinginkan. Berdasarkan hal tersebut sangat diperlukan tenaga-tenaga konselor yang profesional. Pelayanan KB yang berkualitas harus mencakup pemberian pelayanan $(\mathrm{KIP} / \mathrm{K})$ yang dapat melindungi klien dari efek samping dan komplikasi serta meminimalkan kemungkinan terjadinya kegagalan. Walaupun telah dilakukan upaya untuk meningkatkan pelayanan $\mathrm{KB}$, masih terdapat beberapa hambatan dalam penggunaan kontrasepsi, untuk itu diperlukan upaya antara lain dengan memberikan komunikasi interpersonal/konseling (KIP/K) pada sebelum pelaksanaan dan pasca pelaksanaan.

Namun berdasarkan hasil pengabdian masyarakat yang sudah dilakukan, tidak semua klien berminat terhadap alat kontrasepsi IUD dikarenakan berbagai alasan yang berbeda-beda seperti takut efek samping, takut proses pemasangan, dilarang oleh suami. Berdasarkan uraian di atas, maka menurut peneliti, dalam memberikan konseling, khususnya bagi calon klien KB yang baru, hendaknya dapat diterapkan enam langkah yang sudah dikenal dengan kata kunci SATU TUJU. Penerapan SATU TUJU tersebut tidak perlu dilakukan secara berurutan karena petugas harus menyesuaikan diri dengan kebutuhan klien. Beberapa klien membutuhkan lebih banyak perhatian pada langkah yang satu dibanding dengan langkah lainnya.

\section{Penerapan Flash Card Kepada Ibu Hamil Trimester}

\section{III saat home care}

Setelah dilakukan penerapan flash card di BPM Soemidjah dan saat homecare, dilakukan evaluasi kegiatan yaitu setelah persalinan tentang jumlah ibu nifas yang menjadi akseptor IUD. Dari $68 \mathrm{ibu}$ hamil trimester III terdapat $21 \mathrm{ibu}$ yang menjadi akseptor IUD pasca persalinan. [4] perilaku seseorang dipengaruhi oleh pengetahuan, kesadaran dan sikap positif sehingga perilaku tersebut akan bersifat langgeng, sebaliknya bila perilaku itu tidak didasari pengetahuan dan kesadaran maka tidak akan berlangsung lama. Oleh karena itu keikutsertaan ber-KB IUD dipengaruhi oleh pengetahuan ibu yang didapat dari konselingoleh bidan. 


\section{ULASAN KARYA}

Berdasarkan Karya Utama, kelebihan media konseling dengan menggunakan flash card ini adalah ada pengaruh pemberian konseling terhadap perubahan pengetahuan sehingga mampu menaikkan keikutsertaan KB IUD yaitu uji wilcoxon didapatkan $p=0,000$ kurang dari alfa 0,05 .

\section{KESIMPULAN}

Adapun kesimpulan dari Hasil Kegiatan Pengabdian Masyarakat yang dilakukan oleh pengabdi STIKES Widyagama Husada dengan Mitra (BPM Soemidjah Kota Malang) adalah sebagai berikut: Setelah dilakukan analisis menggunakan uji wilcoxon didapatkan $p=0,000$ kurang dari alfa 0,05 yang mempunyai arti ada pengaruh pemberian konseling terhadap perubahan pengetahuan, dan 2) Setelah dilakukan evaluasi kegiatan yaitu dari 68 ibu hamil trimester III yang diberikan konseling menggunakan flash card terdapat 21 ibu yang menjadi akseptor IUD pasca persalinan.

\section{DAMPAK DAN MANFAAT KEGIATAN}

Manfaat dan kontribusi dari kegiatan pengabdian kepada masyarakat ini dirasakan sesuai dengan harapan yang dirumuskan sebelum pelaksanaan, yaitu meningkatkan pengetahuan dan keikutsertaan KB IUD pasca persalinan. Kebermanfaatan dan kontribusi dari program ini diidentifikasi dari beberapa aspek selama masa perencanaan, pelaksanaan dan setelah program berakhir, sebagai berikut: 1) Manfaat dan kontribusi dari masa perencanaan program. Masa perencanaan program yang berupa penyusunan rencana pelaksanaan, survey awal BPM dan wawancara dengan Bidan pemilik BPM, menunjukkan bahwa kegiatan pengabdian masyarakat ini bermanfaat dan berkontribusi sebagai sarana pengembangan dan sosialisasi ilmu pengetahuan. Sarana pengembangan yaitu adanya inovasi media konseling menggunakan flash card IUD. Sosialisasi ilmu pengetahuan dilakukan kepada BPM agar diterapkan ke ibu hamil, 2) Manfaat dan kontribusi selama pelaksanaan kegiatan. Melihat dari penerapan flash card dan hasil evaluasi terdapat peningkatan pengetahuan ibu hamil dan keikutsertaan KB IUD adalah bukti bahwa kegiatan ini sangat bermanfaat dan membawa kontribusi positif untuk Wanita Usia Subur (WUS), dan 3) Manfaat setelah pelaksanaan program. Pengetahuan baru yang didapat oleh responden adalah pondasi keajegan perilaku positif ibu, dengan adanya pengetahuan yang baik pula, responden dapat meneruskan informasi mengenai IUD kepada ibu-ibu yang lain sehingga semakin banyak akseptor IUD.

Diharapkan setelah kegiatan ini, Bidan tetap memberikan konseling IUD menggunakan flash card sehingga makin banyak akseptor IUD. Pengabdi diharapkan melakukan pendampingan secara berkala terhadap keberlanjutan dari kegiatan ini dengan melakukan konseling kepada ibu hamil trimester III di BPM maupun rumah pasien.

\section{DAFTAR PUSTAKA}

[1] Kim Y, Kols A, Putjuk F, Heerey M. 2003. Participation by Clients and Nurse Midwives in Family Planning Decision Making In Indonesia. Patient Educ Couns, 50 (3):295-302.

[2] Khotimah, VK, et all. Pengaruh Konseling KB Pada Ibu Hamil Trimester III terhadap Keikutsertaan KB Pasca Persalinan di Kecamatan Sukowono Kabupaten Jember. e-Jurnal Pustaka Kesehatan, vol. 4 (no. 2) Mei 2016.

[3] Majid, NK, et all. Tentang Kontrasepsi Intra Uterine Device (IUD) Di Desa Donoyudan Kecamatan Kalijambe Kabupaten Sragen). 2013.

[4] Notoatmodjo S. 2010. Promosi Kesehatan: Teori dan Aplikasi. Jakarta: Rineka Cipta.

[5] Pinontoan S. Faktor-Faktor Yang Berhubungan Dengan Penggunaan Alat Kontrasepsi Dalam Rahim Di Puskesmas Tatelu Kabupaten. 


\section{PENGHARGAAN}

Ucapan terimakasih yang sebesar-besarnya kami sampaikan kepada pihak-pihak yang telah berperan serta dalam pengabdian masyarakat ini: 1) Dr. Rudy Joegijantoro, MMRS selaku Ketua STIKES Widyagama Husada yang telah memberikan motivas, 2) Kepala LPPMK STIKES Widyagama Husada yang selalu memacu peningkatan kemampuan pengabdian masyarakat bagi dose, 3) Teman-teman dosen dan mahasiswa DIII kebidanan STIKES Widyagama Husad, 4) Bidan Soemidjah, Amd.Keb selaku pemilik dan pemberi layanan di BPM Soemidjah Kota Mala, dan 5) Ibu-ibu yang bersedia menjadi responden. 